\title{
OUDJAVAANSCHE KUNST.
}

\author{
DOOR
}

W. F. STUTTERHEIM.

Aan het slot van zijn «Inleiding tot de Hindoe-Javaansche Kunst ${ }^{1}$ bespreekt de schrijver van dit uitnemende werk zijn standpunt in zake de vraag in hoeverre er kan gesproken worden van een seenheid der Hindoe-Javaansche Kunst) en formuleert als zijn opvatting dat cde doorloopende lijn in geen enkel opsicht onderbroken is geweest en dat het verschil tusschen wat "wij Midden-Javaansche en Oost-Javaansche Kunst noemen, niet "anders is dan het natuurlijk onderscheid, dat binnen iedere «kunst een tijdsverloop van eenige eeuwen teweeg zal brengen. «De Hindoe-Javaansche Kunst is één en ondeelbaar, en zelfs kan - men zeggen, dat de hedendaagsche tempelkunstenaar op Bali - niet anders doet dan het werk der bouwmeesters van den «Diëng voortzetten., ${ }^{2}$

Hoewel na het verschijnen van dit werk weinigen meer een verontschuldiging omtrent onbekendheid met bovengenoemde kunst kunnen putten uit de afwezigheid van een inleidend geschrift, mag het toch, gezien het feit dat onze overzeesche bezittingen nu eenmaal buiten onze gezichtskring plegen te liggen, nog niet uilen naar Athene dragen heeten, in het kort te schetsen waarom het in het aangehaalde gaat.

Het tijdvak waarin op Java een zoogenoemde hindoecultuur moet hebben geheerscht, welk tijdvak met eenige waarschijnlijkheid te plaatsen valt tusschen de vijfde en de zestiende eeuw, heeft voor grootere of kleinere gedeelten, zoowel temporeel als geographisch gesproken, in verschillende vormen sporen nagelaten. ${ }^{3}$

1 Dr. N. J. Krom. Inleiding tot de Hindoe-Javaansche Kunst. 2 dln. 1920.

, Idem. II. pag. 318.

3 De oudste inscripties dateeren waarschijnlijk uit de $4^{\bullet}$ of $5^{\bullet}$ eeuw en werden op West-Java gevonden. De oudste gedateerde tjạ̣ḍi geeft 778. De laatste gelezen hindoeistische inscriptie op Java draagt als jaartal 1486. 
Een van de belangrijkste dezer vormen is de bouwkunst en het is juist deze die in het verloop van haar ontwikkeling aanleiding gaf tot de geciteerde formuleering. De onderzoekers van de resten dezer kunst (want gaaf bleef geen werk ons gespaard), kwamen aan de hand van het gevondene en daaruit afgeleide gegevens tot de slotsom dat, behoudens uitzonderingen, beoordeeld naar geographische ligging zoowel als naar stijleigenaardigheden, de zoogenoemde hindoe-javaansche kunst te verdeelen viel in een groep oudere bouwwerken, welke meerendeels in Midden-Java (voornamelijk de residenties Kědoe, Semarang en de Vorstenlanden) en een groep jongere bouwwerken, welke in Oost-Java (de residenties Kẹ̣iri, Soerabaja en Pasoeroean) werd gevonden. Andere gegevens, gedeeltelijk in gedateerde of dateerbare oorkonden, gedeeltelijk in los voorkomende jaartallen op bouwwerken, gedeeltelijk in latere geschriften vervat, getuigden van een historisch ouder tijdperk op Midden-Java, een jonger op Oost-Java. Daarbij voegden zich de gegevens die Bali bieden kon en welke deden concludeeren dat in de huidige balische maatschappij. een lijnrechte afstammeling van de oudere of gedeeltelijk oudere hindoe-javaansche kon worden gezien.

Een eigenaardig feit echter, namelijk het plotseling vrijwel uitblijven van gegevens en berichten uit Midden-Java en het eerst hiermede gezamenlijk, later afzonderlijk optreden van berichten uit Oost-Java, gepaard aan een duidelijk in het oog springend stijlonderscheid der laatste en eerste bouwwerken van Midden- en Oost-Java, leidde er gedurende langeren tijd toe de scheiding in de hindoe-javaansche kunst van deze landstreken zeer scherp te formuleeren. De vondst van een schakel die, hoewel gebrekkig, toch beide gebieden verbindt, de poorten van Bělahan, deed de scherp getrokken grens weer ietwat vervagen. En het is juist de bedoeling van den hooggeleerden schrijver der Inleiding deze nog meer te effaceeren, de continuïteit van midden- en oost-javaansche kunst, voortgezet op het eiland Bali, te onderstreepen.

Nochtans blijft de strenge scheiding tusschen midden- en oostjavaansch bouwen uit den hindoetijd, vergeeflijk te noemen, daar de verschillen op allerlei gebied vallen na te speuren, daarbij zoo sterk spreken en in het oog vallen, dat men zichzelf afvraagt of daar toch niet iets diepers aan ten grondslag zou liggen. 
Aan de eene zijde heeft men bij sommige der midden-javaansche bouw-complexen van religieuzen aard een bijzondere voorliefde voor systeem opgemerkt die in Oost-Java in belangrijk mindere mate wordt gevonden. Zoo vertoonen de complexen van Båråboedoer, Sewoe, Prambanan in sterke mate deze eigenaardigheid, hetzij dan de geaardheid boeddhistisch, hetzij zij çiwaitisch is. Daarenboven bemerkt men aan de bouwwerken zelve eveneens zulk een systeem, hetwelke met name aan den Båråboeḍoer duidelijk naar voren treedt.

Op Oost-Java zoekt men met moeite naar een diergelijke voorliefde voor systeem; meer en meer ontvangt men den indruk dat de bouwwerken in zichzelf hun voornaamste beteekenis zoeken en vinden. Bij dit verschil in voorliefde voor een systematischen complexbouw voegt zich nu een ander, hetwelk gevonden wordt in de wijze van ornamenteering. Op Midden-Java treft men een ornamentatie aan die in alle opzichten medegaat en correspondeert met den constructieven architecturalen opzet van het bouwwerk, zoowel bezien vanuit voor-indisch, hindoesch standpunt als vanuit westersch bouwbegrip ${ }^{1}$. De ornamentbanden en beornamenteerde vlakken bevinden zich op die plaatsen waar men deze, westersch gesproken, zou verwachten. Het ornament tast de constructieve elementen niet aan, vult slechts de ruimten tusschen deze, accentueert het verloop van krachten of verdoezelt een te sterk spreken ervan.

Zoo althans ziet men geschieden aan de meeste tempels van Midden-Java.

Op Oost-Java anders: het ornament verliest meer en meer zijn verband met de constructieve elementen, wordt op oogenschijnlijk willekeurige plaatsen aangebracht, dreigt ten slotte, naar de geldende opvatting, het bouwwerk te overwoekeren, zooals op Bali de poeri van Sangsit aan de oppervlakte tot ornament lijkt gecristalliseerd.

Ten derde werd men getroffen door het onderscheid in bewerking en plaatsing der reliefpaneelen.

Op Midden-Java een naturalisme, spiritualistisch, dat in reëele beelden een duidelijke taal spreekt, voor hen die met den gang van zaken in de verbeelde voorstellingen bekend waren gemakkelijk te verstaan; aangebracht op een plaats die duor het

1 Men denke hier bij voorkeur aan het westen zooals het de voortbrenger was der middeleeuwsche bouw werken. 
systeem waarvan het geheele bouwwerk getuigde, hetzij dan çiwaitisch, hetzij boeddhistisch, werd bepaald.

Op Oost-Java een zonderlinge styleering die dadelijk denken deed aan de huidige wajangvormen, van een monotoniteit van figuratie die de uitbeelding soms onherkenbaar makte en aangebracht op plaatsen waar geen hindoe uit het «klassiek» VoorIndië er over zou denken reliefs aan te brengen.

Het is waarlijk geen wonder dat deze typische verschillen deden spreken van een middenjavaansche en daarvan onderscheiden oostjavaansche kunst.

Hoe heeft men nu getracht deze verschillen tusschen de meerendeels oudere middenjavaansche en de jongere oostjavaansche kunst te verstaan?

Over het algemeen heeft men geen weerstand kunnen bieden aan de menschelijke neiging er een degeneratie in te zien. ${ }^{1}$ Men vermoedde dat, naarmate de tijd waarin van een levendig contact tusschen Java en Voor-Indië sprake kan geweest zijn, verder in het verleden kwam te liggen, de meer en meer op zichzelf aangewezen javaan de voorlichting en lessen van zijn hindoeleermeesters moest missen en bijgevolg zijn gebrekkige krachten, immers niet gesteund door een hoogere cultuur als die der hindoes, zoo goed en zoo kwaad als het ging moest aanwenden om de traditie verder te voeren, waaruit dan een regressie in aesthetische praestatie voortsproot.

Maar dan moest men een al te groot aandeel der hindoe's in de totstandkoming der middenjavaansche kunst veronderstellen, wat weer niet klopte met het javaansch karakter van het in de Båråboeḍoerreliefs uitgebeelde.

Een ander geeft den javaan het volle aandeel in MiddenJava maar laat hem arbeiden volgens de oude tradities, hindoetradities, vastgelegd in de çilpaçâstra's; om tenslotte naar het oosten toe zijn kunst te laten verschrompelen en degenereeren, nadat hij de oude leerboeken meer en meer over boord werpt en vervangt door eigen inzicht. ${ }^{2}$

1 De opvatting van "den goeden ouden tijd" is merkwaardig hardnekkig en duikt, alle wetenschappelijke objectiviteit ten spot, telkens weder op. Zelfs Strzygowski laat in zijn ijver "den goeden ouden tijd" der klassicisten de kroon van het hoofd te nemen, zelf de door hem op den troon verheven oud-arische nomadenornamentiek in de kunst der islâm "völlig degenerieren". Zie: Altai-Iran und Völkerwanderung. 1917 pag. 272.

2 Dr. F. D. K. Bosch. Een hypothese omtrent den oorsprong der Hindoe- 
Een ander noemt het onderscheid slechts een dat door een lacune in het oog springt; zonder die lacune, waarbij o. a. Goenoeng Gangsir dienst doet als verbindende schakel, vermoedt hij een logische opeenvolging en ontwikkeling, zooals in het bovenaangehaalde werd geformuleerd en waarvan het eindpunt op het huidig Bali gevonden zou worden ${ }^{1}$.

Weder een ander ziet scherp daarentegen het onderscheid tusschen Midden-Java als gebied van hindoesche kunstuiting en Cost-Java als dat van indonesisch sieren. Zoo sterk, dat wij lezen hoe de geestelijke zin van de door den hindoe aangewende vormen aan den indonesiër onbegrepen zou zijn voorbijgegaan. De oorzaak van het onderscheid zoekt hij in het verschil in geestesgesteldheid der twee volkergroepen: Hindoes en Indonesiërs ${ }^{2}$.

Het kan niet ontkend worden dat met name de eerste opvattingen in hun beredeneering en uitwerking uitgaan van een standpunt dat een stellingnemen verraadt ten opzichte van de aesthetische ontwikkeling der hindoe-javaansche kunst. Ware het mogelijk het niet scherp geformuleerd, doch tusschen de regels te lezen oordeel in een curve uit te drukken, dan zou deze, met wisselingen en schokken, de neiging vertoonen zich naar beneden voort te zetten en aldus verraden dat de beoordeelaars van meening zijn dat de beste hindoe-javaansche kunst aan of bij den aanvang, in Midden-Java kan gevonden worden, de praestaties met ongelijkmatig versnelde beweging afnamen in waarde, tot zij, volgens sommigen, op Bali weder in kracht en beteekenis toenamen om dat op te leveren wat tegenwoordig als balische kunst allerwege zoozeer wordt geprezen.

Hoewel de basis, waarop de laatstvermelde opvatting gegrondvest is, naar moderne begrippen, wel de juiste kan geacht worden wil men trachten het karakter van een kunst te benaderen, toch zijn er in den opbouw en verwerking eenige lacunes die een hernieuwd pogen met gebruikmaking van deze basis mogen wettigen.

Javaansche kunst: Handelingen van het eerste Congres van de taal-, landen volkenkunde van Java. Solo. 1919. pag. 93 vlg.

$1 \mathrm{Krom}$. Inleiding. II. pag. 318.

2 T. B. R(oorda) in Encyclopaedie van Nederlandsch Indië. II. pag. 484 b. S. v. Kunst (Beeldende). Zie ook: D r. K. Wit h. Java, Folkwang-Verlag, 1920, pag. 119-120, en de daar gegeven karakteristiek. De schrijver huldigt ongeveer dezelfde opvatting als welke in dit artikel is neergelegd, motiveert deze echter, voorzoover het Oost-Java betreft, alleen stijl-critisch. 
Wat is dan de geestesgesteldheid der makers van het grootere deel der middenjavaansche kunst, zooals deze uit den steen spreekt?

Reeds eerder maakten wij melding van een eigenaardigheid die in deze bouwkunst in bijzondere mate naar voren treedt: het systeem. En van de middenjavaansche is het weder de boeddhistische die deze eigenaardigheid in de sterkste mate bezit. De trits Mendoet, Pawon, Båråboeḍoer is er om dit aan te toonen; voorts de tempelcomplexen van Loemboeng en Sewoe. Maar ook het groote çiwaitische tempelcomplex van Prambanan vertoont een streng doorgevoerd systeem.

Niet slechts in ligging, oriëntatie der tempels in het complex, ook in de onderlinge verhouding ten opzichte van de beteekenis der godheden waaraan zij zijn gewijd.

Zoo troont in den Mendoet de aardsche afspiegeling van den lichtboeddha Amitâbha, gezeten als predikende de heilsleer; zoo tronen naast hem twee begeleidende bodhisattva's, Avalokiteçwara en Mañdjoeçrî of Vadjrapâni. Al weten wij niet aan welke figuur uit het theistisch-boeddhistisch pantheon het tusschen en op één lijn met Mèndoet en Båråboeḍoer gelegen Pawontempeltje was gewijd, de stoepa zelve, Båråboeḍoer, is zoozeer een steen geworden systeem in de opeenvolging van zijn terrassen, in de concentrische subordinatie van zijn gaanderijen, in de verdichting der uiteengeslagen vormdeelen naar boven toe, tot de eerst gedeeltelijke afgeslotenheid in de à jour bewerkte stoepa's, ten slotte tot de absolute saamgetrokkenheid in den hoofdstoepa, dat hier een blinde het systeem kan tasten ${ }^{1}$. En voor wien deze en andere genoemde voorbeelden niet overtuigend mogen zijn na een bestudeering hunner projecties en doorsneden, resten nog de complexen van Plaosan en Loemboeng.

Echter nog verder dan orientatie en subordineering gaat het systeem. Zoowel de aan de bouwwerken voorkomende reliëfplastiek als de in het inwendige of aan het uitwendige geplaatste vrije plastiek, godenverbeeldingen, boeddha's, blijken een volstrekt bepaalde plaats aan het bouwwerk in te nemen. Reeds werd gewezen op den Çâkyamoeni, den aardschen boeddha, met zijn twee begeleidende bodhisattva's in den Mrndoet. In aansluiting hiermede vertoonen de buitenwandpaneelen van dezen

1 T. v. Erp. Oudheidkundige aanteekeningen I. T. B. G. 53 p. 582 vlg. 
tempel bodhisattvauitbeeldingen in een systematische verdeeling over de beschikbare of beschikbaar gestelde vlakken, ${ }^{1}$ vertoont de voet van het hoofdgestel dier- en andere figuren die daar staan als symbolen van djâtaka's, geschiedenissen uit een der vorige levens van den verlichte, ja zelfs heeft men meenen te moeten opmerken een samenstel van figuren die door gebaren en houdingen den geloovigen beschouwer den door hem te volgen vereeringsweg rond het monument aanwijzen. ${ }^{2}$

Aan den Båråboeḍoer reeksen van reliëfpaneelen die geleidelijk den beschouwer uit de geschiedenissen van den aardschen boeddha opvoeren naar de werelden der toekomst, naar de rijken van toekomstige boeddha's, naar de leer zelve als beredeneering van wat hij, met een plotselingen overgang, op de bovenste, van ornamentatie vrijwel verstoken cirkelvormige terrassen als hoogste realiteit vindt verzinnebeeld, de wereld der mijmerboeddha's, waar de schijnbare werkelijkheid van begrensden vorm is vervangen door de scheidinglooze eenheid van het al, bovenzinnelijk, reëel. Ook in de çiwaitische Prambanangroep kon men zonder veel moeite, een diergelijk systeem ontdekken, ja zelfs deed zij denken aan een brahmaanschen politieken tegenhanger van Båråboeḍoer, waarbij de trits Çiwa, Wiṣnoe, Brahma wijst naar een niet-boeddhistische metaphysiek die, met andere waarden werkend, niettemin de eenheid van het al in den Schepper en Vernieler den geloovige als hoogste realiteit voorhoudt. ${ }^{3}$

Het meest volkomen echter en het verst doorgevoerd voelen wij dezen grondleggenden gedachtengang in het Båråboeḍoercomplex. In subjectieve, naturalistische beeldgroepen gecoördineerd, rijen zich de formuleeringen van ethische begrippen aaneen, overgenomen en verder geleid door andere naar een hooger ethisch peil voerende reeksen, tot het ethisch element vervaagt en ten slotte plaats maakt voor de leer, de metaphysiek van het boeddhisme, in tegenstelling tot de schijnbare veelheid der verschijningen, de reëele wereld der ondeelbare realiteit.

1 Dr. N. J. Krom. De Bodhisattva's van den Mĕndut. Bijdragen. 74 (1918) III. pag. 419 vlg.

2 Dr. J. Brandes. Fout of finesse? in Rapporten van den Oudheidkundigen Dienst. 1913. pag. 24. (1914.)

8 Zie een diergelijke opvatting, hoewel uit later dagen, in: Dr. H. Kern. Over de vermenging van Ciwaïsme en Buddhisme op Java. p. 37 vlg. (overdruk) en Dr. H. Kern-Dr. N. J. Krom. Nâgarakṛtâgama. (1919) pag. 22 vlg. 245 vlg. 
Het is niet moeilijk de geestesgesteldheid te reconstrueeren die ten grondslag gelegen had aan zulk een systeemvol bouwen.

De machtige bovenbouw van het Mahâyâna, welks essentie is de ondeelbaarheid en realiteit van het al, rustend op den breeden onderbouw van wisseling en verschijningswerkelijke vormverschillen, in welke wereld de medevormwordingen der hoogere boeddhaprincipes als rustpunten zijn; dat is die van Båråboedoer.

De çiwaitische, poerânische metaphysiek, uitgedrukt in de subordinatie der verschillende verschijningsvormen van den Algod aan zijn hoogsten vorm, georiënteerd naar sfeer en beteekenis, omhooggeheven op een basis van aan die van Båråboeḍoer analoge, subjectief gegeven wedergave van de afspiegeling in vorm en als onreëel geleerd maar als reëel gevoeld wereldsch gebeuren, dat is die van Prambanan.

Uit dezen architecturalen bovenbouw van metaphysiek over een onderbouw van reliëfplastiek en reliëfornament spreekt een dualiteit die van beteekenis kan genoemd worden. Aan de eene zijde toch vinden wij een verzinken in de eenheid van het al, een opgaan in de alziel, waarvan de uiting in de kunst een abstractie en objectiviteit vereischt die de philosophische scholen van het boeddhisme kenmerkt en die wel nimmer een geestesproduct van zuidaziaten zal geweest zijn - aan de andere zijde een zich verlustigen in de als schijn te denken wereldsche werkelijkheid, die echter duidelijke kenmerken ervan vertoont voor de makers subjectief gevoelde realiteit te zijn geweest.

Wel is op Båråboedoer de doorgevoerde coördinatie of omgekeerd, de splitsing in tafereelen, gescheiden en gedacht als brokken tijd en ruimte, nog sterk genoeg om het verband tusschen deze twee "werelden " niet geheel te doen wegvallen, houden daarbij de dhyâniboeddha's der nissen bij voortduring de aandacht voor het hoogere gedeelte vast, bij Prambanan ontwikkelt zich een naturalisme dat het verband met de bovenzinnelijkheid van het godssysteem eenigermate doet vergeten. Hier toch is de illusie van een historische en ruimtelijke realiteit de hoofdzakelijke bedoeling van den maker, houden de lengte en gerektheid van sommige dezer paneelen geen verband met de frontale tempelverdeeling.

Wel weer is de plaatsing aan de binnenzijde der balustrade, dus onzichtbaar in het tempelaspect, een concessie aan de eenheid van het geheel. 
Dat dit naturalisme der reliëfs van Midden-Java zich op andere wijze verder heeft ontwikkeld en in deze ontwikkeling tot een andere vormgeving kwam dan het naturalisme dat zich in WestEuropa had ontwikkeld uit het idealisme der vroeg-gothische sculptuur, is een feit van niet te onderschatten beteekenis voor den javaan en het probleem hindoe-javaansche kunst. De ontwikkeling toch der mahâyânistische plastiek vertoont onmiskenbare parallellen met die der christelijke kunst in Europa. Hoezeer wij nog te kampen hebben met een lacunaire kennis aangaande de eerste, aanvangend bij de wereldcultuur der laatantieken en hellenisten die èn in denken èn in vormen de grondleggers waren van wat later eeuwen aan kultureele waarden bezitten, worden wij gedwongen dezelfde riching in te slaan over abstractie, idealisme naar naturalisme, zoowel in het westen als in het oosten. Het is hier allerminst de plaats dieper op deze zaak in te gaan, die voor de oostelijke wereld is wat de christelijke kunst en cultuur voor het westen was - moge het genoeg zijn te constateeren dat het antiidealisme, zooals Dvoŕák het noemt, en dat zich in van Eyck's Arnolfini demonstreert, op Java niet gevonden zal worden. ${ }^{1}$ Bezitten wij in de versteende afspiegeling van een bovenzinnelijke kosmische orde, Båråboeḍoer, een aziatische pendant der gothische kathedralen, evenzeer verwezenlijking van een hooger kosmisch systeem, ná de periode waaruit Båråboeḍoer voortkwam zullen de wegen scheiden. China en Japan hebben, den weg van het Mahâyâna verder bewandelende, om vooralsnog slechts te vermoeden redenen, de kans op voortgaande parallellen met het westen bewaard. Een werk als de lohan van Ling-yen-sze is voor Java ondenkbaar, ook met een javaansche typeering der figuren. ${ }^{2}$

Men heeft goede redenen om aan te nemen dat de boeddhistische bouwwerken van Midden-Java kunnen toegeschreven worden aan de tijdelijke heerschappij der Çailendra's, afkomstig

1 M. Dvořák. Idealismus und Naturalismus in der gothischen Skulptur und Malerei, in Historische Zeitschrift, Bd. 119 (1918) p. 208 vlg. Zie ook wat Dr. Hoesein Djajadin ingrat in zijn Critische beschouwing van de Sadjarah Bantěn (Haarlem 1913) pag. 309-311 opmerkt over de historiographische parallellen.

2 Zie voor af beeldingen: E. Fuhrmann. Das Reich der Mitte. I॰ band van „China", Folkwang Verlag. 1921. 
van Sumatra. ${ }^{1}$ Sumatra ook was het land waar het boeddhistisch contact met het vasteland van Zuid-Azië eenmaal verkregen en wellicht onderhouden was. Wat de resultaten waren van dit contact en in welken vorm deze op Java bekend waren leeren ons onder meer twee merkwaardige boeddhistische geschriften: de Sang Hyang Kamahâyânikan ${ }^{2}$ en de legende van Koeñdjarakarna. ${ }^{3}$ Beter dan naar andere, voorindische, boeddhistische geschriften terug te grijpen is het te trachten naar analogie van wat in deze geschriften wordt uiteengezet een beeld te vormen van de geestelijke gesteldheid van den boeddhist in de eeuwen na Båråboeḍoer. Al dadelijk treft ons het verschil in aard dezer geschriften, parallel loopend aan het verschil van den boven- en onderbouw zooals wij dat bij de midden-javaansche tempels hebben gezien. Aan de eene zijde in den Kamahâyânikan een litterair-philosophische bovenbouw, bestaande uit de uiteenzetting van het ethisch Mahâgoehya der Pâramitâ's, Yoga's, Bhâwanâ's en Âryasatyâni, met die van het kosmogonisch Paramagoehya geschoeid op yogâtjârya-leest. Aan de andere zijde in de legende een zich verlustigen in de wereld der schijnbare realiteit, waarin de primaire waarheden van Skandha, Karma en Samsâra enz., maar met een projectie op de gematerialiseerde Wairotjanawereld, den leek-geloovige worden verduidelijkt. Aan de eene zijde dus een ontmaterialiseerende metaphysiek, aan de andere een tot het leekenniveau neerdrukken van het bovenzinnelijke. ${ }^{4}$

Onwillekeurig denken wij weder aan het parallelle litterairillustratief karakter der middeleeuwsche europeesche plastiek, ondergeordend aan de hoogere eenheid van een systeemvolle architectuur. Het is echter steeds geraden bij het doortrekken van diergelijke parallellen de grootste voorzichtigheid in acht te nemen. Heeft toch de vorsching onzer middeleeuwen de beschikking over een uitgebreid en goed bewerkt materiaal, de studie der javaansche oudheden slechts de hulp van weinige gegevens, welke juist, naarmate men zich meer met Midden-

1 Dr. N. J. Krom. De Sumatraansche periode in de javaansche geschiedenis. Inaugureele rede 1919.

' J. K ats. Sang hyang Kamahâyânikan. 1910. 's-Gravenhage.

${ }^{3}$ Dr. H. Kern. De legende van Kuñjarakarṇa in Verhandelingen Kon. Akademie van Wetensohappen, afd. Letterkunde. Nieuwe reeks. III/3.

4 Een korte schets dezer beide werken in: C. Eliot. Hinduïsm and Buddhism. Londen 1921. III pag. 172 vlg. 
Java gaat bezig houden, schaarscher worden. Zoo zijn èn Kamahâyânikan èn Koeñdjarakarṇa uit veel later tijden (de laatste zelfs zal waarschijnlijk niet verder teruggaan dan tot de $12^{\mathrm{e}}$ eeuw, dus niet minder dan 4 eeuwen na den waarschijnlijken stichtingstijd van Båråboeḍoer!) Niettemin, ook de geestelijke basis van MiddenJava's eenigen stoepa kan slecht een zuiver voorindische genoemd worden en had, als leer, reeds de sumatraansche periode achter den rug ${ }^{1}$. Zonder meer te negeeren zijn dan ook beide geschriften in dit verband zeker niet.

Vergelijken wij nu hetgeen wij opmerkten naar aanleiding van Båråboeḍoer en Prambanan (om deze als typen te blijven bezigen) met wat wij vinden bij die eigenaardige tempels op den Diëng, dan worden wij door twee zaken bovenal getroffen. Ten eerste door het systeemlooze van Diëng- en andere bergtempelgroepen, systeemloos in betrekking tot de overige, voornamelijk boeddhistische complexen van Midden-Java; ten tweede door het ontbreken van reliefverbeeldingen, zoogenoemde sprekende reliüfs.

Waar wij nu reden hebben om aan te nemen dat Diëng en verwanten tot een oudere periode behooren en daarenboven kennelijk çiwaitisch van aard zijn, zouden wij kunnen stellen dat het boven- en onderbouwkarakter van Prambanan onder invloed zou staan van de boeddhistische bouwperiode.

Laten wij dan ook Diëng een oogenblik ter zijde, zoo zouden wij als geestesgesteldheid die de meest eigenlijke middenjavaansche tempelcomplexen draagt kunnen formuleeren:

1. Een in systematisch distribueeren en subordineeren der verschijningsvormen van het boeddhistisch kosmisch principe gezochte benadering van de hoogste realiteit als bovenbouw, gedragen en ingeleid door een onderbouw van litterair-illustratieve uitbeeldingen van subjectief gevoelde en naturalistisch verwerkte brokken religieuse historie in doorloopend en oploopend verband van sterk didactisch-ethisch karakter. (Båråboeḍoer).

2. Een herhaling hiervan op çiwaitischen grondslag doch met een beperkten onderbouw die den beschouwer niet opvoert

1 Ik wil hier slechts even de aandacht erop vestigen dat in den Kamahâyânikan ethiek, yoga en kosmogonie de hoofdschotels vormen, daarentegen van de doorgevoerde philosophieën der noord-boeddhistische scholen niet veel meer dan een weersohijn over is. 
uit de onreëele wereld tot de bovenzinnelijke realiteit, doch het goddelijk principe in de wereld der verschijnselen materialiseert. (Prambanan). ${ }^{1}$

Het is er verre van als zouden wij op Oost-Java, waarheen het nu tijd wordt onzen blik te richten, plotseling alle eigenaardigheden zooals wij er enkele van nader beschouwden en formuleerden, missen of tot onherkenbaar wordens veranderd aantreffen. Wel zoeken wij er tevergeefs naar een systematischen complexbouw, doch de algemeene opzet der bouwwerken afzonderlijk vertoont een sterke mate van verwantschap met MiddenJava, welke verwantschap na het ontdekken van de poorten van Belahan en andere schakels, boven twijfel verheven werd.

$\mathrm{Er}$ is echter een andere eigenaardigheid in de architecturale vormgeving die zich bij beschouwing der oost-javaansche tjandii's naar voren dringt, mits wij enkele, waarvan de waarschijnlijkheid groot is dat zij onder vreemde, tjamsche, invloeden gestaan hebben uitzonderen. Deze eigenaardigheid is de neiging tot contractie van de tempelkern, een insnoering tusschen dak en soubasement, die noodwendig gepaard moet gaan met een meer uitgesproken dienend karakter van voet en overkapping dan wij op Midden-Java troffen, bijgevolg met een verbreking der eenheid van het gebouw als opgaand monument en een accentueering van den tempelteerling. Het dak nadert door de verdichting en ineenschuiving zijner ornamenteerende en constructieve elementen tot het begrip pyramidale overkapping door middel van horizontaal laagsgewijs aangebracht materiaal. Voor een vergelijking komen, zooals vanzelfsprekend is, slechts

1 Het studiefotomateriaal is voor Midden-Java nog tamelijk verspreid. Behalve de foto's van den Oudheidkundigen Dienst, die uit den aard der zaak voor een kennisname en orienteering, vanwege hun zeer groot aantal, minder geschikt zijn, vindt men in de Rapporten der Oudheidkundige Commissie een groot aantal detailfoto's gereproduceerd, als verduidelijking van enkele artikels en studies betreffende oudjavaansche kunstwerken. Tot een monographie is het met één middenjavaansch bouwwerk gekomen. (Dr. N. J. $\mathrm{Krom}$ in het $3^{\circ}$ deel der monographiënreeks). De in de Inleiding beschikbare ruimte stond natuurlijk, hoewel helaas, het plaatsen van meer detailfoto's niet toe, te meer daar, als wij het wel hebben, de schrijver bij de keuze zijner 100 platen zich heeft laten leiden door een trachten naar volledigheid. Zeer goede foto's geeft eveneens Dr. K. With in zijn: Java. Folkwangverlag 1920. (Zie hierbij eohter de opmerkingen van Krom in: Nederlandsch Indië Oud en Nieuw. Jaarg. 1921.) 
die midden- en oostjavaansche tempels in aanmerking die, door althans gedeeltelijk aanwezig zijn van het dak, eenigermate een beeld kunnen verschaffen van wat de intuitieve bouwgedachte moet zijn geweest. In dit geval behoeft de vergelijking van Kị̣al, Bangkal en de poorten eenerzijds, met Bimå, Poentådewå, Pawon en M̌ndoet anderzijds geen commentaar; mogen daarbij de balineesche prasada's de consequentie van deze neiging demonstreeren.

Deze contractie wekt de gedachte op aan een intensiveering der beteekenis van de tempelkern en het is dan ook in deze dat wij iets anders zullen aantreffen, iets wat bij het werk der boeddhistische midden-javaansche ontwerpers niet wordt gevonden.

Het feit doet zich namelijk voor dat een zeker percentage der ons overgeleverde oostjavaansche tiandi's zich heeft ontpopt als bijzetplaats van een vorstelijk persoon. Behalve waarschijnlijk een urn met asch werd soms in den tjaṇdi (althans in een paar gevallen hebben wij hieromtrent eenige zekerheid) een çiwaitisch c. q. boeddhistisch beeld geplaatst dat als receptaculum zoowel van de ziel van den afgestorven vorst of voorname persoon, als van den algeest waarmede hij geidentificeerd werd, kon optreden ${ }^{1}$. Hoewel door deze laatste identificatie het verband tusschen een dergelijk bouwwerk en een uit het middenjavaansche tijdperk, waarin de hoogste godheid in haar verschijningsvormen als kosmisch principe vereerd zou geworden zijn, sterk genoeg was om een te krachtig afwijken van de oude vormgeving te voorkomen, wordt hier in meerdere of mindere mate iets algemeens verbijzonderd. Het valt toch niet te ontkennen dat het systeembeeld hetwelk wij van uit de oudere periode voor oogen hebben en waaraan een metaphysischkosmogonische gedachtengang ten grondslag lag, van een andere geestesgesteldheid getuigt dan de vereering van een godheid in een goddelijke uitbeelding van een historischen persoon, naar de leer, in werkelijkheid wel eerder omgekeerd: de vereering van de ziel van den afgestorvene, opgegaan in de alziel ${ }^{2}$. Het van

1 J. L. Moens. Hindu-Javaansehe portretbeelden in Tijdschrift Bataviaasoh Genootschap voor $\mathrm{K}$. en W. LVIII pag. $493 \mathrm{vlg}$.

3 Hoe wij. ons de geaardheid van die alziel of algeest, wiens identificatie met Çiwa een poging tot vormgeving medebracht, moeten voorstellen is niet overduidelijk. Als wij het wel hebben en deze geaardheid zou overeenkomen met die welke K. Beth in zijn: Religion und Magie bei den Naturvölkern op pag. 164 vlg. voor de Dajaks uiteenzet, dan moest wel elke poging tot 
afzonderlijke kenmerken voorzien van het godsbeeld legt een sterker accent op het laatste dan wel op het eerste. De centralisatie in het persoonlijk element verraadt een gedachtengang die grondt in het bereiken van nuttig effect eerder dan een opvoeren tot een hooger levenspeil. In deze en dergelijke gevallen zou dan de beteekenis van het bouwwerk zich concentreeren op het begrip: "ziele-monument, zieletempel, tempel waarin zich de ziel van den afgestorven vorst, opgegaan in de goddelijke alziel en daarom te machtiger, den volke als beschermer aanbiedt. Zoo concentreert zich ook de beteekenis van den architecturalen opzet op dat gedeelte waar het contact met de vorstenziel-alziel kan plaats vinden: de tempelkern. Niet door een verzwaring van dat bouwdeel, maar door een andere rol die het krijgt te vervullen. Niet langer wordt het gedacht als een deel eener kosmische afspiegeling, een gecondenseerde visie van het al, een abstract compositie-schema, maar als een begrensde realiteit, als een aan materieele vormen gebonden terrein van goden -- c. q. zielewerkzaamheid.

Ongemerkt zijn wij terecht gekomen in indonesisch denken. Een dergelijke opvatting doet onze gedachten onwillekeurig gaan naar de uit den archipel overbekende vereering der afgestorvenen. Zonder daarbij echter aan een causaal verband of ook maar aan een verwantschap te denken, kan het zijn nut hebben in deze richting verder voort te gaan, temeer daar het çiwaisme zich op Java meer en meer als een den javaan minder vreemd dan het boeddhisme liggende godsdienst ontpopt en ook op het vasteland van Zuid-Azië dergelijke elementen in zich bergt.

Waar wij reeds zagen dat de tjanḍi zelve in zijn opzet door een scherper begrenzen van het hoofdbeeld in het terrein van diens werkzaamheid meer en meer het kosmisch karakter verliest, zien wij het beeld zelf langzaam maar zeker en in de jaren na den bloei van den laatsten grooten officieel-hindoeistischen staat, Mådjåpahit, met zeer groote snelheid in vormgeving naderen tot het indonesisch begrip "zielebeeld". "Naderen" drukt niet juist uit wat er geschiedt. Zoowel in het vorsten-godsbeeld, de identificatie van de individueele ziel met de oerziel, den oppergeest, als in het indonesisch voorouder- of zielebeeld, vinden wij eigenschappen van vorm en lijn, die ons als teruggaande

vastlegging, ook met behulp van een vreemden vormenkanon, noodwendig falen, hoogstens uitloopen op een naar dezen kanon gewijzigd zielebeeld. 
tot op één en dezelfde basis, treffen; van gelijken is hier natuurlijk geen sprake, daar in het eerste geval de hindoeistische vormkanon zijn eischen stelt. Doch evenzeer als de middeleeuwsche kerkelijke persoonsverbeeldingen in elementairen opbouw getuigen van een aan laat-antieken ontleenden vormkanon, evenwel in de voortgezette ontwikkeling meer en meer adaequaat worden aan den spiritueelen inhoud, die zich deze vormgeving koos - zoo constateeren wij van de oudste der hindoejavaansche Çiwabeelden tot in de laatste tijden na Mådjåpahit toe, een vrij geregeld te volgen toenemend naar voren treden van die eigenschappen welke ons bij polynesische voorouder- en zielebeelden treffen.

Allereerst dan wel de vaak als aesthetisch-technische regressie gekwalificeerde neiging tot verstarring. De bhangga, de bij oudere, voorindische beelden zoo geliefde doorbuiging in het middel, die zelfs bij den Wiṣnoe van Banon nog valt op te merken, verdwijnt en maakt plaats voor het lijkachtige der latere Çiwafiguren. Hier en daar noteeren wij een vergrooting van het hoofd als uit «iel»kundig oogpunt meest belangrijk gedeelte van het lichaam. ${ }^{1}$ Ten slotte ontwikkelt zich om het lichaam een stralenfond dat wel lastig anders te begrijpen valt dan als de zichtbaarmaking der uitstraling van levensvuur, de magische zielegloed, en als zoodanig niet alleen in vorm een uitbreiding van het aureool.

Dit alles wil natuurlijk allerminst beteekenen dat de javaan in zijn tjandi's er een voorouderdienst op na hield waarbij voorouderbeelden te pas kwamen als welke wij van elders kennen, nu gemodificeerd tot een Chiwa-vorstenfiguur. Eerstens is omtrent de verbreidheid en de algemeene beteekenis der bijzetting in Ciwa- en andere godsbeelden nog weinig met zekerheid bekend. Ten tweede weten wij evenmin veel aangaande een officieelen Çiwadienst en den vorm waarin deze gegoten was. Doch slechts moeten wij ons voor oogen stellen dat de javaan niet meer of niet in deze beelden die kosmische beteekenis voelde als welke wij op Midden-Java aantroffen en daarbij ons de vormveranderingen zóó trachten te verduidelijken, dat wij een steeds sterker in vorm uitgedrukt wordende identificatie van den çiwaitischen oppergod met het indonesisch begrip oppergeest, machtigste

1 K rom. Inleiding II plaat $87 a$. R a p porten. 1908 (1910) PI. 98-100. With: Java PI. $149-152$.

DI. 79 . 
geest, erkennen, waarbij datgene wat aan maleisch-polynesische expressionistische zielebeelden ten grondslag ligt zich ook in de vormgeving dezer beelden naar voren dringen gaat.

De sfeer waarin dan de vereering van het hoofdbeeld uit den tjaṇ̣i zich verplaatst ziet is die van de geestenwereld, nauw verwant aan die der afgestorvenen en het is in deze sfeer dat wij ons moeten verplaatsen als wij de overige verbeeldingen, de reliefs, willen verstaan.

De daarin afgebeelde verhalen toch blijken voor het overgroote deel te bestaan uit episoden zooals wij er uit oudere bronnen, Mahâbhârata en Ramâyaṇa, kennen, waarbij andere, door ons niet gekende, zich voegen. Misschien mag men veronderstellen dat deze episoden meer en meer betrokken werden in de mythische historie van den javaan. Hoewel de officieële geschiedschrijving de helden uit deze verhalen voorloopig nog niet als historische elementen erkent en dit eerst in het namådjåpahitsche tijdperk zijn beslag krijgt, zal althans het volk hen gezien hebben als persoonlijkheden van eigen ras, van eigen land; zulk volksinzicht blijft nimmer zonder invloed, zelfs op de officieel gehuldigde opvattingen. Hierbij ondergaat de sfeer waarin zich deze geschiedenissen afspelen een duidelijk naspeurbare javanisatie. Niet in dien zin als waarvan men pleegt te spreken bij de javanisatie aan Båråboeḍoerreliefs, doordat kleederdracht, omgeving der personen, huizen, planten etc. javaansch zijn en niet uitbeeldingen van in Voor-Indië voorkomende typen, doch zoodanig dat de historische figuren tot geestfiguraties worden, hun omgeving vervuld is van geesten en geestelementen, kortom de geheele scène zich afspeelt in een als geestenwereld te denken milieu, op zich zelf een reëele wereld, waarin de evenzeer reëele geest wordt gematerialiseerd, vorm verkrijgt. Wat in de volksgedachte leefde aan onuitgebeelde doch door conventie geheiligde voorstellingen omtrent den verschijningsvorm der deels goede, deels booze vooroudergeesten, der lucht-, aard- en watergeesten en wat er meer in het geestenarsenaal van den javaan aanwezig moge zijn, dat grijpt een onder hindoeleiding wellicht verkregen technische vaardigheid en uitbeeldingsvermogen, benevens den ganschen vormenkanon aan om zich te kunnen uiten, om zich een vormgeving te verschaffen.

Daarbij is het vanzelfsprekend dat indonesische i. c. javaansche 
rasidealen, grondend in voorteekenleer en magie, bij de verwerking en omzetting dezer vormenschool naar de oppervlakte dringen ${ }^{1}$. Sterker echter en voornamelijk wordt het beeld veranderd door de "vergeesting". Het frontale, tweedimensionale, de massaloosheid, de verstarring, niet slechts javaansche, maar meer algemeene eigenschappen van het begrip "geest» als nalevende en nawerkzame schaduwziel van een afgestorvene, komen in steeds schriller tegenstelling te staan tegenover de materieele picturaalplastische uitbeelding van aardsch beleven der hindoereliefs.

Het wegwerken der ruimteillusie door vervlakken, in tegenstelling met het verwekken ervan op Midden-Java is een voorname eisch geworden. ${ }^{2}$ Door de lucht zweven reëele geesten. Beschermgeesten begeleiden de helden. En wie zich nog niet in een gematerialiseerde geestenwereld verplaatst mocht voelen,

1 Men vergelijke de bij $\mathrm{H}$. A. van $\mathrm{Hien}$, De javaansche geestenwereld, op pag. 65 van deel II (1896) gegeven: Hal wirasatnja orang. Zie ook: B. L a u fer. Das Citralakshona. Leipzig 1913. pag. 28 vlg.

3et kan, als wij dieper op deze verschijnselen ingaan, waartoe het echter hier niet de gelegenbeid is, ons niet verbazen in de verwerking van hindoeistische randplastiek en reliefplastiek door den javaan, eigenschappen te ontdekken die ook elders en met door materiaal en voorstudies begunstigd succes, zijn nagespeurd en die W. Worringer in zijn "Abstraktion" formuleert in tegenstelling met de "Einfühlung". Mutatis mutandis is deze voorstelling van de aesthetische werkzaamheid ook voor Java van beteekenis. Waar hij zegt (Abstraktion und Einfühlung 1919. pag. 28): „Zur An„näherung der Darstellung an die Ebene wurde man gedrängt, weil die Drei"dimensionalität einer Auffassung des Objektes als einer geschlossenen ${ }_{n}$ stofflichen Individualität am meisten entgegensteht, indem ihre Wahrnehnmung ein Nacheinander von zu kombinierenden Wahrnehmungsmomenten „erfordert, in dem die geschlossene Individualität des Objektes zerfliesst _, en (pag. 29) „Die Unterdrüokung der Raumdarstellung war schon deshalb ${ }_{n}$ ein Gebot des Abstraktionsdranges, weil es der Raum gerade ist, der die „Dinge miteinander verbindet, der ihnen ihre Relativität im Weltbilde "gibt, und weil der Raum sich eben nicht individualisieren lässt" - daar denken wij aan de reliëfs en het in het vlak verwerken der godenfiguren.

En ais wij lezen (pag. 50): „Musste doch diese Nachformung” (d.i. de rondplastische driedimensionale) "in ihrer Unklarheit für die Wahrnehmung "und in ihrem Zusammenhang mit dem unendliohen Raume den Betrachtenden „in denselben quälenden Zustand lassen wie gegenüber dem Naturvorbild", dan zien wij de nog op Bali voorkomende rondplastiek van deurwachters, garoed̦a's, nâga's, kortom alle min of meer schrikaanjagende figuren. Hier is dezelfde ruimtevrees in het spel, die wij elders in den archipel antreffen en die meer en meer een rol krijgt te spelen in de verklaring der primitieve ornamentiek. 
hem zij aangeraden zijn aandacht te wijden aan de, op tjạ̣ḍi Djago bijzonder reëel uitgebeelde, vlamelementen, die gedeeltelijk reeds aan dezen tjandi, sterker nog aan Panataran in gecompliceerden vorm symbolen, hiëroglyphen mogen heeten van het in hooge mate en machtig bezield en ver"geest» zijn van de sfeer waarin zich de episoden afspelen. ${ }^{1}$ Dat deze geestenwereld met de zichtbare wereld ineenloopt, weet men; de javaan kent zijn geesten een naar zijn zin wel al te groot aandeel toe in den gang zijner zaken. De wereld zooals hij die weet maar niet ziet, is hier door hem symbolisch vastgelegd, gedeeltelijk zelfs reëel. De magisch-gunstige kenmerken, die hij zich en zijn grooten wenscht, heeft hij in en met de hindoeistische vormgeving verwerkelijkt. ${ }^{2}$

Zoo worden de twee voornaamste deelen van het bouwwerk: het hoofdbeeld als contactplaats van den goddelijken geest en de reliëfs als begeleidende, niet langer inleidende, de sfeer kenmerkende, in vorm vastgelegde heldengeschiedenissen, vergeest d.w. z. reëel gegeven. Een fixeering dus van wat in de volksgedachte leefde en reeds langer had geleefd. Naast de in hindoevormen gefixeerde indonesische voorstellingen van nu eerst historie geworden voorouderfiguren, treden op de in het vlamelement vastgelegde geesten, door de lucht vliegende reuzen en dwergen, diergestalten, monsters, etc. etc.

Waar nu een der meest kenmerkende eigenschappen van een geestesgesteldheid als uit dezen veranderden stand van zaken

1 Over de vlam als magisch-krachtsymbool en levenselement zie: Mr. F. D. E. van Ossenbruggen, Het primitieve denken enz. in Bijdragen. 71 (1916) pag. 44 vlg. (§ 39 vlg.).

2 Men heeft in de fantastische dier- en menschvormen van Panataran een javaansch impressionisme willen zien dat in wolken en bergenuitbeelding tot uiting kwam. Het komt ons voor dat bij een geestesgesteldheid als van den javaan weinig sprake kan zijn van een zoo sterke individualiteit als een impressionisme in uitbeelding wel zou vereischen. Men veroorlove een derde anhaling uit Worringer's boekje (pag. 50): „Dass fernerhin eine rein „impressionistische Darstellung, die das Naturvorbild nicht in seiner Realität, „sondern in seiner Erscheinung wiedergibt, ausgeschlossen war, ist selbst„verständlich, denn eine solche Darstellung hätte auf jede Wiedergabe des „objektiven Tatbestandes verzichtet und hätte in ihrer ausgesprochenen subnjektivität einem Drange nicht genügt, der, von dem Willkürlichen der „Erscheinung gequält, eben nach dem „Ding an sich" haschte." Wij voor ons zien hier een realiteit in die uitbeelding der geesten door middel van het vlam- of zieleëlement, (dat in zijn meest eenvoudigen vorm zou terug te brengen zijn tot de spiraal) magisch-machtig en symbolisch. 
spreekt, wel is de afwezigheid van een scherp omlijnde en omlijnende klassificeering en systeemvol indeelen en verklaren van het kosmisch probleem ${ }^{1}$, wat zich zoo sterk uitte in de op den achtergrond gerakende geestesgesteldheid der middenjavaansche ontwerpers, daar mogen wij ons niet verwonderen, ja daar verwachten wij niet anders als wij het verband der beteekenissen der bouwdeelen zien vervagen, wegvallen ten slotte.

Iedere zich daartoe leenende ruimte is welkom tot het doen opnemen van wat de javaan zich als magisch, den te vereeren goddelijken geest aantrekkend en lokkend, denkt. Mits dan ook de centrale positie van het hoofdreceptaculum, godsbeeld, geen schade lijdt, kan de reliëfbeeldhouwer zijn gang gaan waar hij wil. Het uitgebeelde is niet meer gesubordineerd aan de conceptie van het bouwwerk maar staat op zich zelf. Het is, zooals het op Bali nog wordt omschreven, aměngameng, dat wat aangenaam is. Het eenige doel is het aan den geest adaequaat maken van zijn tjaṇdi.

Zoo worden de scheidingen der episoden niet door een constructieve paneelverdeeling, opgevat als behoorende bij den bouw zelf en zijn indeeling, tot stand gebracht, doch behooren zij in het verhaal, worden in het leven geroepen door elementen uit de reliëfbewerking; ja, waar de traditioneele paneel- en pilasterverdeeling aan het soubasement den beeldhouwer voor de keuze stelt welk van beiden voor een sierend, zwaar ornament te gebruiken (juist de architecturale vormleer was hardnekkig om reden van haar aan den javaan oneigen karakter), kan hem dit geen zorgen baren. Integendeel wij komen in de verleiding te veronderstellen dat hij liever, zooals o. a. bij Panataran geschiedde, de pilasters zal kiezen om zoo te ontkomen aan een te scherp omlijnen zijner reliëfverbeeldingen, waartoe een paneelgebruik aanleiding kon geven. De pilaster toch zal, door het weglaten van afsluitende onder- en bovenlijsten, hem in staat stellen zijn geestenwereld achter de paneelen om als doorloopend te denken, zoodat dan de verticale lijsten bij de paneelen en niet meer bij de pilasters zouden behooren.

Hoe dit ook zij, het moge uit het bovenstaande eenigermate duidelijk geworden zijn dat de tjaṇdi niet meer is een ver-

1 Zie in verband hiermede: Dr. H. Kraemer. Een javaansche primbon uit de zestiende eeuw (Leiden. 1921) pag. $124 \mathrm{vlg}$. 
eeringsplaats van een gedefinieerd kosmisch principe, waarbij de verschijningsvormen als hulpbiedend aan den volksgeest en de volksphantasie optreden, maar een scherpe localisatie van een in meerdere of mindere mate machtigen, ongedefinieerden geest op de basis van nuttig effect.

Was het javaansche volk van een geestesgesteldheid geweest als welke spreekt uit bouwwerken van Midden-Java, zoo had zijn kunst zich ongetwijfeld in een geheel andere richting ontwikkeld. Zijn eigen indonesisch denken dreef hem een anderen kant op, daarbij geholpen door het vele wat als eigendom van het volk in Voor-Indië in het çiwaisme hieraan deed aanknoopen. Eerstens klopt zijn ongedefinieerde, sterk subjectieve wereldbeschouwing niet met de gedefinieerde, naar het objectieve trachtende, kosmische der arisch-indische cultuur. Ten tweede was zijn cultureele positie bij lange niet zoo dat zij, ook in den loop der eeuwen dat het hindoe-contact met Java levend moet geweest zijn, opgevoerd zou kunnen worden tot de geestesontwikkeling der hindoes, die een centraalaziatische leerschool doorloopen hadden.

Dus moeten wij in de wijze waarop de javaansche geest het hindoemateriaal en zijn eigen hindoesche scholing verwerkt heeft, niet zien een omlaag wijzende voortzetting van wat op Midden-Java aan kunst en cultuur gevonden wordt, maar een poging van den javaan naar vormgeving en uitbeelding van eigen, indonesische voorstellingen en ideeëncomplexen. Dat hierbij de architecturale, constructieve elementen het minst en de reliëfplastische uitbeeldingen het meest in aspect veranderden, is een logisch gevolg van de waarden die de javaan aan het hem door de hindoes geleerde heeft gehecht. ${ }^{1}$

Beziet men de historische vormontw:kkeling alleen en heeft men daarbij voor Midden-Java niet zoozeer het oog op de aan de boeddhistische bouwwerken en Prambanan ten grondslag liggende geestelijke basis, als wel op met den inhoud correspondeerende

1 En van de plastiek is het weder de rondplastiek der god-vorsten-verbeeldingen die, niettegenstaande alle pogingen haar in het vlak te doen opgran, van welk pogen, zooals wij zagen, de latere çiwa's een duidelijk beeld verschaffen, toch uithoofde van haar beteekenis het langst weerstand biedt aan alle javanisatie en in dezen weerstand misschien wel den grond doet vinden van het feit dat zij het op Bali "moest afleggen". 
vormeigenaardigheden, dan is het zeer goed mogelijk te spreken van een "eenheid der hindoejavaansche kunst». Stelt men de middenjavaansche bouwwerken, mogelijk met uitzondering van Prambanan, als cultuurrichting tegenover Oost-Java en Bali, dan is die eenheid echter minstens even formeel als die van antieken en middeleeuwen. Ook het sterk accentueeren van het çâstrisch element brengt gevaren mede. Want deze çâstra's wortelen in den vorm, handelen over den vorm en bieden, zooals Tibet ons leeren kan, met dat al nog ruimschoots gelegenheid den vorm in zoo sterke mate te wijzigen, ook met letterlijke inachtneming der voorschriften, dat het aspect geheel veranderd te noemen valt. ${ }^{1}$ Daarenboven, het is niet alléén de vorm die kunst representeert.

Hoewel, zooals reeds gezegd is en uit het voorafgaande moge blijken, de derde opvatting door ons in den grond als diegene wordt beschouwd welke de beste kansen biedt in zake het verklaren der oostjavaansche kunst in haar bijzondere eigenschappen, is toch in de toepassing dezer, in europeesche aesthetisch-kritische werken reeds langer gehuldigde beschouwing op de hindoejavaansche kunst, het oostjavaansche tijdperk wel te zeer als een tijdperk van verwording aangezien en het voornaamste veld van indonesische werkzaamheid in dezen eerst op Bali gelocaliseerd. Iets, wat te vergelijken valt met wat wij in de europeesche kunsthistorie aantreffen kunnen bij hen die de voor- en vroegmiddeleeuwsche tijdperken als een voortgezette degeneratie der laatantieken beschouwen en eerst in de gothiek een opkomst van eigen leven in de kunst ontdekken. Dat de doorwerking van het indonesisch geestelijk element reeds veel eerder, op OostJava, ja, wij zouden willen zeggen, in Prambanan, heeft plaatsgevonden, is sedert het verschijnen der "Inleiding " een moeielijk meer te loochenen feit.

Het is er verre van als zouden alle in het oog vallende en nog niet opgemerkte eigenaardigheden der oostjavaansche en balische kunst, een verklaring vinden. Zeer veel blijft onzeker. De geringere aandacht die men over het algemeen, in vergelijking met Midden-Java, dat via de hindoes "anklang» vond aan eigen aesthetisch inzicht, aan de laatste kunst van Oost-Java besteedde,

1 Het Citralakșana b.v., zooals het zich in den bs Tan-'gyur bevindt, blijkt een vertaling te zijn van een helaas niet overgebleven saṃkṛttekst. 
verhinderde tevens dat voldoende materiaal ter beschikking staat, geordend, overzichtelijk, bereikbaar. Daarbij is ook onze kennis van de javaansche geestesgesteldheid uit die dagen, zooals wij die voorloopig wellicht naar indonesische parallellen uit later tijd moeten reconstrueeren, nog evenzeer ongevormd en weinig vastgelegd. Het grootste deel van de geschriften die uit dien tijd over zijn, is nog onuitgegeven en zoo voor breeden kring onbruikbaar.

Naarmate de ethnologische kennis van Java toeneemt, zal ook het inzicht in de kunst van Oost-Java zich kunnen verdiepen. Daarbij in de beoordeeling uit te gaan van een kunst met hindoenormen op Java in een historische ontwikkeling, moet noodwendig tot een ongunstig oordeel over de praestaties van den javaan leiden, waar hij zoogenoemd op eigen beenen kwam te staan. Ziet men echter in de hindoejavaansche kunst een worstelen en pogen om vormgeving van javaansche voorstelling, aanvangende tijdens en na de midden-javaansche periode, dan kan het niet anders of ons aesthetisch oordeel, dat zal weten te scheiden en te onderscheiden, moet erkennen: het ontstaan van een javaansche kunst, groot-javaansch, als'men Bali er bij wil voegen.

Het hindoeistisch godsbeeld, als te scherpe formuleering van het ondefinieerbare, verdwijnt. De reliëfs gaan als afzonderlijk sfeerkweekend, doch geenszins zinloos bouwdeel een eigen leven leiden; het ornament krijgt evenzeer zijn voornaamste beteekenis in een vergeesting van den tempel, krijgt dus eerder tot taak het niet-menschelijke, natuurlijke te accentueeren dan het menschelijk constructieve, betrekt het bouwwerk onmiddellijk in de omgevende bezielde natuur ${ }^{1}$.

Het bouwwerk, nu gecentreerd om de locale beteekenis en werkzaamheid van den betreffenden goddelijken geest, is geworden tot een adaequate uiting van indonesisch beleven; wat daarbij aan hindoes werd ontleend is slechts middel.

Door de officieele bescherming van den islâm, verviel op Java ook de officieele noodzaak van den oostjavaansche tempelbouw. Maar wat uit het verkregen bezit kon gered worden, bleef behouden: de wajangfiguur.

Keeren wij echter nog eenmaal terug tot Midden-Java en be-

1 Op te merken valt dat het daarbij in hoofdzaak hindoeistisch blijft, echter, althans in eenige streken, de neiging gaat vertoonen in de plaats van de op Java overheerschende weelderigheid van een "Treibhauskultur" (Strzygowski) een indonesische abstractie naar voren te schuiven. 
schouwen wij daar de Diëngtempels als min of meer los van elkaar staande, althans niet geconcipieerd in hun verdeeling en orienteering, naar het systematisch kosmisch plan waarop in bijzondere mate de boeddhistische bouwwerken van Midden-Java zijn geplaatst, dan zouden ook deze, waarschijnlijk oudste der overgebleven tempels geen uiting geven aan de geestesgesteldheid die wij voor de bloeiperiode der middenjavaansche kunst aannemen. Dan zouden er misschien redenen voor gevonden kunnen worden in deze tempels te zien het vroegste, ons bekende, samengaan van een, tal van aanknoopingspunten biedenden, uit hindoeschool voortgesproten çiwaitischen vereeringsbouw in steen met indonesisch geloof aan op of bij bergen huizende geesten of goden. ${ }^{1}$ De plaatsing van deze en dergelijke tempels, hoog boven het niveau van het in de dalen en vlakten geconcentreerd volksleven, het çiwaitisch karakter, het bijzonder karakter der omgeving, wijzen min of meer in deze richting. Daarbij te denken aan het verhaal van den balischen vorst die zich omtrent belangrijke staatszaken op den hoogsten berg met den oppergeest in contact stelde ${ }^{2}-$ tevens aan het vản chineesche zijde verschaft bericht omtrent den vorst van Java die, als de identificatie juist is, op den Diëng jaarlijks de zee ging zien, wat toch wel meer dan een pleiziertochtje zal geweest zijn, is vergeeflijk, maar bevat misschien toch meer dan een toevalligheid. Het lot dat de Diëngtempels deelen moesten met de rest van Midden-Java na de oostelijke verplaatsing van het cultureel overwicht, heeft verhinderd dat ter plaatse de beteekenis van dit plateau kon nagegaan worden.

De javaansche vereeringsnoodzaak van een berggeest zou er mogelijk aanleiding kunnen geweest zijn tot ritueel hindoesch bouwen. Dat dit dan çiwaitisch moest zijn, zou uit het karakter van berggod van den hindoe-Çiwa voortvloeien.

Wij zouden hier dan komen te staan aan den aanvang van dat langdurig proces dat de vormzoeking van javaansch voorstellingsvermogen genoemd moge worden, omtrent dat deel van zijn gedachteleven dat hem het naast ter harte ging door een permanenten druk op zijn levensvrijheid: het geloof aan de reëele macht van voorouderziel en geesten.

1 Dergelijke, niet op of bij bergen gebouwde tempelgroepen zonder systeem vonden dan natuurlijk in andere locale geesten hun bouwoorzaak.

2 A. Wallace. The Malay Archipelago. 
Het is hier niet de plaats om dieper op het hoe en waarom in te gaan. Daartoe is meer noodig dan wat gegeven kan worden uit den huidigen voorraad van materiaalbewerking. Detailstudies met dieper perspectief dan een bouwkundige en iconographische opname, gegrond op kunstwetenschappelijke basis kunnen eerst succes hebben en verhoeden dat kunstzinnig liefhebberen kwaad sticht.

Een verhoogde aandacht voor Oost-Java, in nauw verband met Bali, met ruggesteun van ethnologie en litteratuur is een postulaat voor het oudheidkundig en kunsthistorisch onderzoek op Java, wil dit niet worden uitsluitend tot een studie van wat de hindoe op Java wrocht, maar wil het ook en vooral als doel nastreven: de studie van den javaan in zijn cultur historische beteekenis en ontwikkeling. 